\title{
Apathy, Agency, and Sociocultural Mediation in a University English Course
}

\section{Masayo Kanno \\ UCL Institute of Education, University College London}

\section{Reference Data:}

Kanno, M. (2020). Apathy, agency, and sociocultural mediation in a university English course. In P. Clements, A. Krause, \& R. Gentry (Eds.), Teacher efficacy, learner agency. Tokyo: JALT. https://doi.org/10.37546/JALTPCP2019-18

This paper is a report of an exploratory case study with a learner who showed apathetic attitudes in a Japanese university English course. Previous research indicated the influence of self-perception, learner autonomy, and exam washback effects on Japanese learners' attitudes towards language learning. This study takes a sociocultural approach to contribute to a deeper understanding of the constructive nature of learner agency. Semistructured interviews unexpectedly revealed the learner's multilingual experiences and ongoing self-directed learning efforts outside the classroom. A thematic analysis identified two themes: the ineffectiveness of the classroom learning environment and the importance of English language skills. These themes illustrated that learner agency was mediated through interaction between the learner's subjective opinions and collective attitudes in the classroom. The author discusses pedagogical factors that could enhance learner agency and facilitate learner involvement in language learning.

本論文は、日本の大学の英語の授業内で無関心な態度を示す一人の学習者に関する探求的事例研究の報告である。先行 研究では、自己認識や学習者の自律性、そしてテストの波及効果が日本人学習者の語学学習に対する姿勢に与える影響が示 されている。本研究は、社会文化論的なアプローチから、発展的な性質を持つ学習者行為主体性をより深く理解することを目 的とする。半構造化インタビューでは、多言語に接した経験があり現在自主的に英語を学習していたことが予想外に明らか

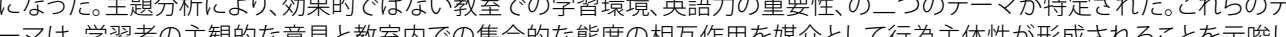
た。著者は、行為主体性を高め、語学学習への関わりを促進することができるような教育的要素を論じる。 pathy in language learning has been problematized in the context of university - EFL courses as it can possibly impoverish classroom teaching and learning (Sugino, 2010; Ushioda, 2013). This paper investigates apathy as a state of indifference and an absence of interest. Student apathy is generally associated with lacking motivation, which has attracted extensive quantitative investigation. This line of research identified self-confidence, classroom atmosphere, teacher behaviour, and future language and professional goals as major factors that potentially influence learner motivation (Apple, Falout, \& Hill, 2013; Falout \& Maruyama, 2004; Johnson, 2013; Tanaka, 2017; Yashima, 2009). Apathetic behaviours, however, could derive from other elements, such as the nature of classroom activities, hesitations, and sensitivity to others (King, 2012). As part of a larger research project, this paper qualitatively investigates one apathetic learner appearing specifically resistant to classroom learning activities. Drawing on the concept of agency to examine conscious and unconscious choices made in specific social settings, I explored how agency was negotiated and co-constructed in the social and cultural context of a university English course. This would be beneficial for language practitioners to obtain insights into apathy in a classroom and different modes of agency involved.

\section{Background}

Agency refers to the capacity or state of individuals to act independently and make their own decisions. It has drawn attention in the area of language learning and teaching due to its connection to learners' choices regarding their actions inside and outside the classroom (Ahearn, 2001; Lantolf \& Pavlenko, 2001; Toohey \& Norton, 2003). However, agency is a contested concept. There has been discussion about whether agency is an inherent property of an individual learner or a concept with social aspects. Toohey and Norton (2003) saw agency as an autonomous and subjective decision-making process and emphasise learners' control over their choices. This view is in line with Duff (2012), who treated agency as a property possessed by the individual. However, Block (2015) argued that the social context affects individuals' choices; thus, agency is not a completely individual trait. 
In this paper I draw on Vygotsky's sociocultural theory and examine language learning as human development rather than knowledge acquisition (Lantolf \& Poehner, 2014). Humans are social, in that they change their behaviour through their relations with their surrounding environment (Vygotsky, 1930/1978). For the purpose of this study, agency is the relative capacity of individuals to act, constantly negotiated between the individual, subjective experiences, and the current social environment (Dufva \& Aro, 2015; Lantolf \& Pavlenko, 2001). It is individually and collectively shaped with various degrees of intentionality through sociocultural mediation (Ahearn, 2001).

Previous researchers have discussed these subjective and dialogical aspects of learner agency and how it interacts with language learner autonomy and motivation. Agency can be subjectively shaped by learners' strong sense of multilingual identity. This enhances their positive involvement in language learning and efforts to gain access into the target language community (Cervatiuc, 2009; Lee, 2014). However, agency can be constrained or enhanced through sociocultural mediation in a classroom environment. A disjuncture between students' imagined learning community and the teacher's curriculum goals could result in resistance to learning (Norton, 2001). Increased teacher's control would possibly restrict learner autonomy and motivation (Lamb, 2011). This echoes Murphey and Jacobs's (2000) claim that collaborative autonomy encourages learner agency in a classroom. Teacher-learner interactions could also mediate learner agency (Hirano, 2009), reinforcing and strengthening a learner's self-esteem and self-regulation in language learning.

In an EFL context in Japan, exam-centred culture is also influential to language learner agency. University EFL learners have been described as being silent, apathetic, and disengaged (Harumi, 2010; King, 2012; Sugino, 2010). Their negative attitudes in a classroom are frequently attributed to the consequences of exam-oriented language learning (McVeigh, 2001; Ushioda, 2013). Most secondary students who aim to enter a university focus on achieving a high score on the National Center Test for University Admissions (hereinafter the Center Exam). This generates a goal-oriented and testfocused culture that could be referred to as washback effects (Allen, 2016). Such learners may not see the link between English for exams and English for communication (Kobayashi, 2001). Thus, English becomes purposeless following university entrance.

Exam washback effects are not limited to negative consequences. Although many apathetic learners may fail to see the purpose of university EFL courses, the popularity of the TOEIC test indicates that there is still a need for language proficiency exams (Taguchi, 2013). Such exams are mainly used to demonstrate efforts for knowledge development, rather than to genuinely acquire practical language proficiency (Kubota,
2011). Nevertheless, they can increase extrinsic motivation driven by external rewards, such as better employment opportunities, even when learners are not intrinsically interested in language learning (Deci \& Ryan, 2012; Messick, 1996). Yashima (2009) reported that extrinsic motivation correlated with learners' interest in their international and professional future-self more than intrinsic motivation did. She implied that studying English could help learners relate themselves to international communities. It can be said that exams possibly have a positive impact on language learner agency, even if the primary purpose is not placed on language acquisition.

To summarise, previous studies have shown that learner agency can be shaped subjectively by multilingual identity and dialogically through the sociocultural context of a classroom. It can also be affected by learners' attitude towards exams. I intend to illustrate ongoing changes in learner agency through the investigation of these elements. The following research questions are addressed:

RQ1. Is a seemingly apathetic learner in a university English course actually as apathetic as they look?

RQ2. What aspects of agency can be seen in this specific sociocultural context of classroom language learning?

\section{Method}

An exploratory qualitative case study approach was taken, being well suited to an intensive investigation into a specific case in a certain social and cultural learning context of a classroom (Duff, 2014). The study focused on 2nd-year engineering undergraduates who were classified into the lowest English group by an entrance placement interview at a Japanese university. The students had studied for a year with the same classmates at the time when I began teaching them. Classroom atmosphere was sometimes noisy with some students distracted at times. However, most students were engaged in classroom activities, which contradicted my expectation based on the group's general reputation and my previous experience with students in the lowest level classes in the subdepartment of engineering.

The EFL course met twice a week for 15 weeks and followed the university's standardised curriculum using an approved textbook. After having been centred around oral communication activities in Year 1, the focal course was aimed at developing reading and presentation skills. 


\section{Participants}

Of six students who were invited and agreed to join in the larger research project, this study is focused on Shu (pseudonym), in order to gain a deeper understanding of learner agency with one single participant. Sampling was purposive as learners who showed apparently apathetic behaviours in the classroom were recruited. As a guideline, student behaviours identified as having a negative impact on language teachers' motivation to teach or support their students were sought : (a) sleep, (b) take a rebellious attitude, (c) do not verbally respond, (d) are not interested in studying, (e) forget to do homework (Sugino, 2010).

Shu demonstrated all these aspects at least during the sampling period, Weeks 1 to 3. He tended to fall asleep, never talked to the teacher, and gained low scores on biweekly vocabulary tests. I approached him in Week 4 with an expectation to elicit negative perspectives on language learning. Informed consent was received from both him and the university administration.

\section{Data Collection and Analysis}

The main data collection method was semistructured interviews. Grounded in sociocultural theory, the study identified interviews as social interactions in which both interviewer and interviewee engage in data co-construction (Talmy, 2010). Two interviews were conducted about two months apart in Week 5 and Week 14. The initial interview lasted for an hour and asked about Shu's background and goals for English language learning. The second interview was a follow-up that elaborated on interesting issues and checked for changes in his perspective, which took 20 minutes. Both interviews were audio recorded and then transcribed. Notes were taken for nonverbal features, such as facial and emotional expressions, so as to later recollect the social atmosphere of the interview context (Kvale, 2007). Inductive thematic analysis was conducted to investigate whether there were interesting patterns or inconsistencies in the data. This helped contextualise subjective opinions and collective attitudes in the classroom and in the wider social context (Saldaña, 2015). The procedure was conducted entirely in Japanese.

To ensure the validity and credibility of a qualitative study, it is necessary to address reflexivity and reflectivity, because my positioning in the research context could possibly influence the data collection and analysis. As a Japanese teacher of English, I experienced a similar educational path as the students. I was a goal-oriented and testfocused non-English major undergraduate who focused on receptive language abilities (see Allen, 2016); this motivated my continuous efforts to encourage students' learner autonomy, such as becoming involved in decision-making about learning contents and proposing deadlines for coursework. When this research project was conducted, I was working closely with the school of engineering and occasionally encountered students in hallways, including Shu. In order to make this qualitative research process visible, I maintained a systematic journal on the social and situated process of knowledge construction throughout this study. This action was also aimed at enhancing the credibility of data with close investigation into the research context (Lincoln \& Guba, 1985).

\section{Findings}

Despite my expectations of gaining negative perspectives, Shu surprised me with his multilingual experiences and initiative in self-directed language learning outside the classroom. This section first presents his multilingual experiences that appeared as a crucial element of his agency construction. It then describes two themes generated from 25 codes identified in the interview data: ineffectiveness of the classroom learning environment and the importance of English language skills. The interview excerpts are my translation of Japanese utterances.

\section{Multilingual Experiences}

Shu had lived in a Western European country with his family for 3 years, aged 10 to 12 . He went to a Japanese primary school where he studied English and French as a foreign language. He spoke basic French to communicate with people in town and English as a lingua franca at interschool events with students who spoke different languages. He had seen his father working as an engineer in a multinational environment. Even after returning to Japan, Shu saw his father leave home early in the morning for international video conferences.

He also revealed a story of recent multilingual work experience, which had encouraged him to study English on his own. Two months before the initial interview, he stayed and worked in a ski resort in the Tokyo area during spring break. There he worked with an Australian colleague and foreign customers for a month, which encouraged him to improve his English skills and better communicate with them. Exchanges with the colleague during and after work specifically helped shape his identity as an English speaker and rethink the need for higher English skills. 


\section{Ineffectiveness of the Classroom Learning Environment}

Shu shared his long-standing view that it was difficult to acquire English in the sociocultural context of a Japanese classroom. This view greatly affected his current apathetic classroom attitudes. His multilingual experiences in Europe never encouraged him to study English as a subject; rather, they kept him from studying it. Holding the strong view that English is a language rather than a school subject, Shu could not find the meaning of studying English in a classroom environment and even hated it.

When I was in junior high school, I couldn't clearly see the purpose for studying English. I really hated "repeat after me" activities. I didn't understand the meaning of repeating a text in chorus very slowly after a Japanese teacher. I refused to do that. I have long thought that English is a language. We haven't studied to speak Japanese, right? That's the answer. (Initial interview)

As university entrance exams approached, Shu struggled with the reality that he needed to study English for exams, not for communication purposes. His practice exam scores were below average. A few months before the Center Exam, he stopped fighting with himself, deciding to improve his grammar and vocabulary. As a result, his score increased and exceeded the national average for the Center Exam.

I have wanted to be able to speak English and I never disliked English so much, but . .. well, I hated to study only for exams. I knew my score was low because of my poor grammatical knowledge ... I wasn't feeling good as it was. Right before the Center Exam, I thought I definitely needed to begin studying grammar and vocabulary. I forced myself to study a lot, then I could get a score at least above the average. After all, I had no choice but to study for exams. (Initial interview)

Shu maintained an indifferent attitude in university EFL classes. Even though Year 1 classes focused on the development of oral communication skills, he still could not see the meaning of classroom activities. Placed in the lowest level class with students who generally appeared uninterested in language learning, Shu was never satisfied with the conversation practice. His multilingual experiences in real-life settings again inhibited his accepting the value of the classroom learning environment.

\section{The Importance of English Language Skills}

Despite his disengaged attitudes in the classroom, Shu demonstrated confidence in believing in the importance of English language skills. However, levels fluctuated as the semester progressed. In the initial interview, he demonstrated his self-perception as an English speaker, which indicated a strong sense of multilingual identity. His recent work experience at a ski resort had triggered his initiative in improving his English skills and facilitated self-directed language learning. Ironically, his approach was exam-driven, but he was purposefully using the TOEIC test in order to motivate himself to develop basic knowledge.

When I was talking to my Australian colleague, I figured "Oh, I definitely needed to speak English better." We all hope to talk more properly, right? Around the end of the spring break, I decided to study for the TOEIC test, bought a vocabulary book, and installed a smartphone app for test practice. Now I am trying to improve listening skills and expand my vocabulary. Getting a high score is not my goal, ... but living in Japan, this is what I can do to motivate myself. (Initial interview)

However, there was a decline in his self-regulative attitude between the two interviews. In the follow-up interview, Shu revealed a weaker interest in language learning, referring to a decrease in his study time from every two days to once or twice a week. He attributed this to the current sociocultural environment in that he never had an opportunity to use English after returning to normal life. He mentioned that he was becoming busier with his studies but never made an excuse. In the next extract, he blamed himself for being easily distracted:

I am losing my interest as I get busier. I don't use English in my everyday life. .. I really understand English is necessary, still now. I know I need to study English, but I get easily distracted. My schedule is packed. But the stronger sense of urgency makes me think I should force myself to make time to study English. ... I guess I'd better destroy my smartphone. (Follow-up interview)

At the end of the follow-up interview when I was debriefing the session, Shu hesitantly shared his feeling that he was empowered through the interaction with me as a teacher-researcher. He smiled and mentioned the positive impact of the interview on his self-directed learning. To my surprise, he was even thankful to me for giving him opportunities to reflect on and talk about his language learning journey.

But when this sort of thing (interview) happens, well, I would start studying again. ... It's actually good. I guess I will study today, definitely I think. My gut is telling me. (Follow-up interview)

\section{Discussion and Conclusion}

The interviews unexpectedly revealed Shu's past experiences and current learning environment that could help explain how his classroom attitude had been shaped. In 
this section the findings are discussed, and research questions answered with reference to classroom occurrences recorded in the reflective journal. The findings will be used to illustrate how learner agency can be subjectively and collectively shaped and to explore three different modes of agency that were socially and culturally mediated through incidents in and outside the classroom.

RQ1. Is a Seemingly Apathetic Learner in a University English Course Actually as Apathetic as They Look?

Findings suggested that the answer is partly yes, while definitely no. Although Shu appeared apathetic in the classroom, he was trying to improve his English independently. His multilingual experiences had affected his perspectives towards classroom language learning. However, these seem to have been alleviated as the course progressed.

Shu's strong sense of multilingual identity triggered two viewpoints that possibly shaped his negative classroom attitudes. First, his resistance to classroom activities could have been caused by a disconnection between his multilingual identity and exam-oriented language learning activities (Kobayashi, 2001; Norton 2001). His desire to acquire oral communication skills was never fulfilled by the way English was taught at school. Next, the teacher-centred, exam-focused learning environment possibly had negative washback effects (Allen, 2016; King 2012). Competitive, rather than collaborative or communicative, classroom atmosphere could have led to his lack of confidence and disengagement in classroom activities (Apple, et al., 2013). Even though he had recently initiated self-directed language learning, he did not seem to expect much from classroom language learning.

It is worth noting that Shu gradually became more actively involved in the focal English course. The reflective journal indicated that his positive involvement increased after the initial interview. He became more engaged in reading and vocabulary exercises, took the initiative in deciding on a group presentation topic, and gave a presentation with confidence. This could imply that his sense of autonomy was developed perhaps by the teacher's efforts to enhance autonomous classroom learning and by increased classroom interaction after the interview (Johnson, 2013; Lamb, 2011). Additionally, the presentation activity seemed to match his preferred learning style, strengthened his sense of multilingual self, and helped construct his agency.
RQ2. What Aspects of Agency Can Be Seen in This Specific Sociocultural Context of Classroom Language Learning?

The findings revealed three different modes of agency that were mediated through the various incidents over time. First, Shu showed his initiative in self-directed language learning, which was subjectively shaped by his efforts to gain access to the Englishspeaking community (Cervatiuc, 2009; Lee, 2014). His multilingual self once alienated him from exam-focused language learning at school (Norton, 2001), but his recent work experience helped construct his agency to become a better English speaker (Toohey \& Norton, 2003). He used the TOEIC test as an external reward to evaluate his English skills, keep himself engaged, and maintain his agency (Messick, 1996; Taguchi, 2013).

The second mode of agency entailed sociocultural mediation in the classroom and immediate social environment (Dufva \& Aro, 2015; Lantolf \& Pavlenko, 2001), in which subjectively shaped agency underwent ongoing negotiation with others. Agency was reshaped in the sociocultural context of a classroom with disengaged peers (Lamb, 2011; Tanaka, 2017) and was also collectively mediated in his everyday life where there was little social need for English (Ahearn, 2001). Finally, his reshaped and weakened agency was again co-constructed through the interviews as a social interaction (Talmy, 2010). Shu positioned and repositioned himself in the given social context by repeatedly addressing how each of his decisions were made. This could reassure himself, reinforce his self-esteem, and encourage his ongoing journey towards being a more effective user of the English language (Hirano, 2009).

\section{Pedagogical Implications}

This study drew on a case with one student who had unusual language-related experiences; however, it has implications for pedagogical practices that can possibly shape learner agency in a positive way. First and foremost, creating a collaborative atmosphere in the classroom would be crucial in order to give a positive sociocultural impact on individual learners. Even when the initial classroom atmosphere is apathetic, this case study suggested that there may be learners who have an interest in improving their English skills. Apathetic attitudes could derive from various sociocultural factors, such as disengaged classroom atmosphere or resistance to specific classroom activities. If teachers ensure that learners cooperate with each other and contribute their own ideas, this could facilitate autonomous learning (Murphey \& Jacobs, 2000). 
Next, despite a general belief of test aversion in a university classroom, exams would possibly give a reason for learners to get involved, at least in an EFL context in Japan (Kubota, 2011). As Shu's experience shows, exams should not be used for their own sake, but should be used or designed for learners. As Yashima (2009) put it, "The visions of learners as ideal L2 users can be created through educational initiatives" (p. 159). If exams could properly address the target language skills and the interests of a specific learner group, they could enhance learner agency with positive washback effects (Messick, 1996).

Finally, as this study indicated that interviews could serve as a forum for knowledge construction, teachers could work more closely with learners to help them pursue better language learning practices. This sociocultural knowledge co-construction not only gives teachers new insights but also allows learners to feel involved. The intervention can take the shape of interviews and group discussions. Even if no practical ideas come up, the teacher's listening to learners' voices could strengthen their self-esteem (Hirano, 2009), which will potentially enable more active involvement in learning (Falout \& Maruyama, 2004). University English courses can offer an opportunity for a teacher and learners to collaboratively seek better language learning practices. This will possibly help accommodate apathetic learners and get them ready for further adventures in language learning.

\section{Acknowledgments}

I would like to thank two anonymous reviewers and Professor Howard Brown for their valuable comments and suggestions, which helped me improve earlier drafts of this article. I also thank Professor Hugh Nicoll for sharing his insights into learner development. My gratitude goes as well to Dr. Mehmedbegovic-Smith and Dr.

Diamantidaki for their supervision of the research project of which this paper is a part.

\section{Bio Data}

Masayo Kanno is an EdD candidate at UCL Institute of Education and currently teaches at universities in Fukui and Sendai. Her research interests include learner agency, identity, teacher emotion, ESP, and materials development. <kanno.masayo@gmail.com>

\section{References}

Ahearn, L. M. (2001). Language and agency. Annual Review of Anthropology, 30(1), 109-137. https://doi.org/10.1146/annurev.anthro.30.1.109

Allen, D. (2016). Japanese cram schools and entrance exam washback. The Asian Journal of Applied Linguistics, 3(1), 54-67. Retrieved from https://caes.hku.hk/ajal/index.php/ajal/article/view/338

Apple, M. T., Falout, J., \& Hill, G. (2013). Exploring classroom-based constructs of EFL motivation for science and engineering students in Japan. In M. T. Apple, D. Da Silva, \& T. Fellner (Eds.), Language learning motivation in Japan (pp. 54-74). Bristol, England: Multilingual Matters.

Block, D. (2015). Structure, agency, individualization and the critical realist challenge. In P. Deters, X. Gao, E. R. Miller, \& G. Vitanova (Eds.), Theorizing and analyzing agency in second language learning: Interdisciplinary approaches (pp. 17-36). Bristol, England: Multilingual Matters.

Cervatiuc, A. (2009). Identity, good language learning, and adult immigrants in Canada. Journal of Language, Identity, and Education, 8(4), 254-271. https://doi.org/10.1080/15348450903130439

Deci, E. L., \& Ryan, R. M. (2012). Motivation, personality, and development within embedded social contexts: An overview of self-determination theory. In R. M. Ryan (Ed.), The Oxford handbook of human motivation (pp. 85 -107). New York, NY: Oxford University Press.

Duff, P. A. (2012). Identity, agency, and second language acquisition. In The Routledge handbook of second language acquisition, 14 (pp. 410-441). Abingdon, England: Routledge.

Duff, P. A. (2014). Case study research on language learning and use. Annual Review of Applied Linguistics, 34, 233-255. https://doi.org/10.1017/S0267190514000051

Dufva, H., \& Aro, M. (2015). Dialogical view on language learners' agency: Connecting intrapersonal with interpersonal. In P. Deters, X. Gao, E. R. Miller, \& G. Vitanova (Eds.) Theorizing and analyzing agency in second language learning: Interdisciplinary approaches (pp. 3953). Bristol, England: Multilingual Matters.

Falout, J., \& Maruyama, M. (2004). A comparative study of proficiency and learner demotivation. Language Teacher, 28(6), 3-9. Retrieved from www.jalt-publications.org/tlt/articles/2004/08/ falout

Harumi, S. (2010). Classroom silence: Voices from Japanese EFL learners. ELT Journal, 65(3), 260269. https://doi.org/10.1093/elt/ccq046

Hirano, E. (2009). Learning difficulty and learner identity: A symbiotic relationship. ELT Journal, 63(1), 33-41. https://doi.org/10.1093/elt/ccn021

Johnson, M. P. (2013). A longitudinal perspective on EFL learning motivation in Japanes engineering students. In M. T. Apple, D. Da Silva, \& T. Fellner (Eds.), Language learning motivation in Japan (pp. 189-205). Bristol, England: Multilingual Matters.

King, J. (2012). Silence in the second language classrooms of Japanese universities. Applied Linguistics, 34(3), 325-343. https://doi.org/10.1093/applin/ams043 
Kobayashi, Y. (2001). The learning of English at academic high schools in Japan: Students caught between exams and internationalisation. Language Learning Journal, 23(1), 67-72. https://doi.org/10.1080/09571730185200111

Kubota, R. (2011). Questioning linguistic instrumentalism: English, neoliberalism, and language tests in Japan. Linguistics and Education, 22(3), 248-260. http://dx.doi.org/10.1016/j.linged.2011.02.002

Kvale, S. (2007). Doing interviews. https://dx.doi.org/10.4135/9781849208963

Lamb, T. E. (2011). Fragile identities: Exploring learner identity, learner autonomy and motivation through young learners' voices. The Canadian Journal of Applied Linguistics, 14(2), 68-85. Retrieved from https://journals.lib.unb.ca/

Lantolf, J. P., \& Pavlenko, A. (2001). (S)econd (L)anguage (A)ctivity theory: Understanding second language learners as people. In M. P. Breen (Ed.), Learner contributions to language learning: New directions in research (pp. 141-158). Harlow, England: Pearson Education.

Lantolf, J. P., \& Poehner, M. E. (2014). Sociocultural theory and the pedagogical imperative in L2 education: Vygotskian praxis and the research/practice divide. Abingdon, England: Routledge.

Lee, E. J. E. (2014). Motivation, investment, and identity in English language development: A longitudinal case study. System, 42, 440-450. https://doi.org/10.1016/j.system.2014.01.013 Lincoln, Y. S., \& Guba, E. G. (1985). Naturalistic inquiry. London, England: Sage.

McVeigh, B. J. (2001). Higher education, apathy and post-meritocracy. The Language Teacher, 25(10), 29-32. Retrieved from http://jalt-publications.org/old_tlt/articles/2001/10/ mcveigh

Messick, S. (1996). Validity and washback in language testing. Language Testing, 13(3), 241256. https://doi.org/10.1177/026553229601300302

Murphey, T., \& Jacobs, G. M. (2000). Encouraging critical collaborative autonomy. JALT Journal, 22, 220-244. https://doi.org/10.37546/JALTJJ22.2-1

Norton, B. (2001). Non-participation, imagined communities and the language classroom. In M. P. Breen (Ed.), Learner contributions to language learning: New directions in research (pp. 159-171). Harlow, England: Longman.

Saldaña, J. (2015). The coding manual for qualitative researchers. London, England: Sage.

Sugino, T. (2010). Teacher demotivational factors in the Japanese language teaching context. Procedia-Social and Behavioral Sciences, 3, 216-226. https://doi.org/10.1016/j.sbspro.2010.07.036 Taguchi, T. (2013). Motivation, attitudes and selves in the Japanese context: A mixed methods approach. In M. T. Apple, D. Da Silva, \& T. Fellner (Eds.), Language learning motivation in Japan (pp. 169-187). Bristol, England: Multilingual Matters.
Talmy, S. (2010). Qualitative interviews in applied linguistics: From research instrument to social practice. Annual Review of Applied Linguistics, 30, 128-148. https://doi.org/10.1017/S0267190510000085

Tanaka, M. (2017). Examining EFL vocabulary learning motivation in a demotivating learning environment. System, 65, 130-138. https://doi.org/10.1016/j.system.2017.01.010

Toohey, K., \& Norton, B. (2003). Learner autonomy as agency in sociocultural settings. In D. Palfreyman \& R. C. Smith (Eds.), Learner autonomy across cultures (pp. 58-72). New York, NY: Palgrave Macmillan.

Ushioda, E. (2013). Foreign language motivation research in Japan: An 'insider' perspective from outside Japan. In M. T. Apple, D. Da Silva, \& T. Fellner (Eds.), Language learning motivation in Japan (pp. 1-14). Bristol, England: Multilingual Matters.

Vygotsky, L. S. (1978). Mind in society: The development of higher psychological processes. Cambridge MA: Harvard University Press. (Original work published 1930)

Yashima, T. (2009). International posture and the ideal L2 self in the Japanese EFL context. In Z Dörnyei, \& E. Ushioda (Eds.), Motivation, language identity and the L2 self (pp. 144-163). Bristol, England: Multilingual Matters. 